\title{
Development of Bacteria in Waters Stored in Glass Containers
}

\author{
By C. B. TAYLOR AND V. G. COLLINS \\ Freshrvater Biological Association, Wray Castle, Ambleside, Westmorland
}

SUMMARY: The factors affecting the growth of bacteria in fresh water stored in different containers, usually glass, were studied in order to reconcile the different results which have been obtained by previous workers. Growth occurred in two sites-in the body of the water and at the surface of the container-and was affected by the constituents of the container.

Bacteria invariably grew on the sides of the container and were presumably dependent for their multiplication on having a site of attachment; thus the increase in the count per unit volume which occurred when bottles were vigorously shaken was greater in small bottles than in large bottles, and was due to removal of some of the cells attached to the walls. Bacterial growth was stimulated by soluble chemical substances in the walls of containers; Bohemian glass and the glass of measuring cylinders were stimulatory; Pyrex glass and fused silica containers were inactive. It is probable that under the conditions of their experiments some workers have been observing bacteria which were dependent on the glass surface for their existence and which were unable to multiply in the body of the water sampled.

Since the publications of the Franklands (1894) and Whipple(1901) it has become well established that when fresh water or sea water is stored in glass containers bacteria multiply rapidly to numbers which are often far in excess of those found under natural conditions. But although it is agreed that the phenomenon takes place the cause remains a matter for discussion. The subject has been reviewed in detail by ZoBell \& Grant (1943) and by ZoBell (1946). It has usually been found that the number of bacteria developing in a glass container is related to its size, appreciably greater numbers being found in waters stored in small vessels than in large; but Castell \& McDermott (1941) found no such relationship. Lloyd's (1937) tests were made in narrow-mouthed cylindrical Pyrex jars of capacities 100,1000 and $8000 \mathrm{ml}$, and the plate count from the $100 \mathrm{ml}$. jar was approximately three times those of the samples from the 1000 and $8000 \mathrm{ml}$. jars, which did not differ significantly. The phenomenon was not dependent on the ratio of surface area of the liquid to volume. ZoBell \& Anderson (1936) concluded that the development of a denser population in the smaller vessel was due to the greater ratio of surface area of the container to volume and to the ability of certain types of bacteria to multiply on a glass surface. ZoBell (1943) later suggested that the nutrient organic matter from the water is concentrated by adsorption on the glass surface, and that solid surfaces retard the diffusion of exoenzymes and hydrolysates from the cell. This hypothesis of adsorption of organic matter received some support from Stark, Stadler \& McCoy (1938), and from Harvey (1941). It is based first on the well-established fact that on glass surfaces in contact with natural waters sooner or later develops there an attached film of bacteria which can be demonstrated by staining; secondly, on claims that chemical methods can detect and measure 
the matter adsorbed on the glass surface. However, Harvey (1941) was unable to demonstrate significant amounts of organic matter by the alkaline potassium permanganate method, and the often-quoted paper by Stark et al. (1938) gives neither details of the bichromate method used, nor any quantitative data.

The phenomenon of growth of bacteria in stored waters is of more than academic interest; it is an example of the growth of bacteria in extremely dilute solutions. The hypotheses of adsorption and consequent concentration of organic matter on the glass sides of the container from the stored water, and the enzyme concentration theory of ZoBell (1943) are not wholly consistent. On the one hand the growth of bacteria in waters transferred to containers is rapid, and maximum numbers are usually found on the second or third day after filling; on the other hand, the development of attached bacteria is much slower, and appreciable numbers, as demonstrated by direct methods, do not occur until some time later (ZoBell \& Stadler, 1940, Fig. 2). With regard to organic matter on the glass surface the published results of chemical tests are quite inadequate to prove its existence. Moreover, any organic matter present might be bacterial protoplasm and not due to adsorption of soluble compounds from the water. Furthermore, chemically clean dry glass is capable of reducing potassium permanganate in the absence of organic matter (Taylor, 1947), so that past experiments using glass beads and glass tubes might have been falsely interpreted. The need for controls in this type of work is obvious.

Methods. Except where otherwise stated, samples of water were collected in Winchester quart bottles and brought to the laboratory within $1 \mathrm{hr}$. of collection. Samples from Lake Windermere were taken at a depth of approximately $1 \mathrm{~m}$. in mid-lake. The samples were dispensed into the various experimental containers and, unless otherwise stated, incubated at a temperature of $20^{\circ}$. Plate counts were made in peptone casein starch glycerol medium (Taylor, 1940) employing 3-5 replicate Petri plates/sample. The plates were incubated for 12 days at a temperature of $20^{\circ}$.

\section{EXPERIMENTAL}

\section{Development of bacteria in containers}

Multiplication in lake water; the effect of temperature. Plate counts were made at $2 \mathrm{hr}$. intervals for a period of $26 \mathrm{hr}$. from two $500 \mathrm{ml}$. samples of Windermere water contained in Winchester bottles; one bottle was incubated at room temperature $\left(17 \cdot 2-20^{\circ}\right)$ and the other at $20^{\circ}$. Both containers were agitated vigorously before removing the samples. The counts in both samples were stationary during the first $12 \mathrm{hr}$. From the 12 th hour onwards counts increased in both samples but more rapidly in that kept at the slightly higher temperature. At $26 \mathrm{hr}$. the counts were $130,000 / \mathrm{ml}$. in the $20^{\circ}$ sample and $14,800 / \mathrm{ml}$. in the 17.2-20 $0^{\circ}$ sample (Fig. 1).

The effects of the material of the container on multiplication of bacteria. Three tests were carried out with Windermere water in containers of different material. In the first test $500 \mathrm{ml}$. samples were held in $(a) 11$. Pyrex conical flasks, (b) 11 . flint glass bottles and $(c) 11$. tall bottles made of gutta percha. 
In the second test 1 l. conical flasks of Pyrex, Bohemian glass, and of fused silica ('Vitreosil') of almostidentical shape were employed. In both experiments three replicate containers of each kind were used, and the figures given in

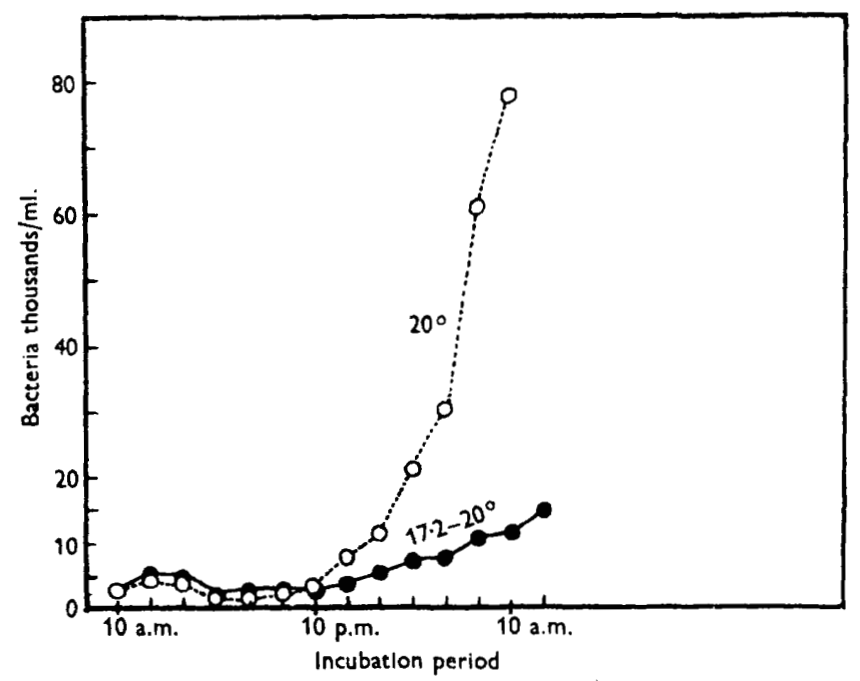

Fig. 1. Plate counts of bacteria at $2 \mathrm{hr}$. intervals in Windermere water incubated at $20^{\circ}$ and room temperature $\left(17 \cdot 2-20^{\circ}\right)$ in 11 . Winchester bottles, with vigorous shaking on each sampling occasion. $\mathrm{O}-\cdots-2^{\circ}$

$17 \cdot 2-20^{\circ}$.

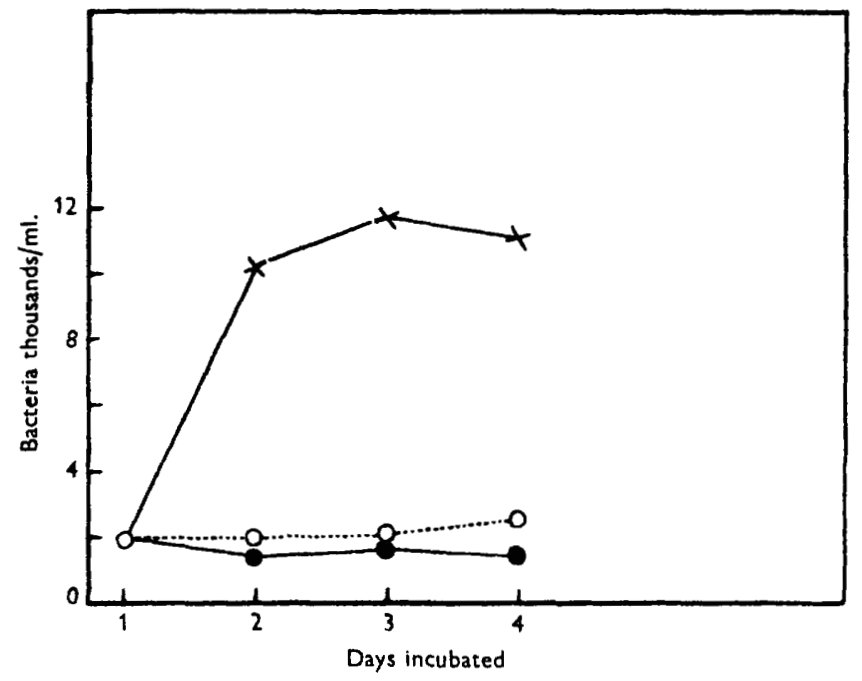

Fig. 2. Plate counts of bacteria in Windermere water incubated in $1 \mathrm{l}$. conical flasks of different chemical composition for 4 days at $20^{\circ} . \times-\times$ Bohemian glass; $\mathrm{O}--\mathrm{O}$ Pyrex glass;

Table 1 and Fig. 2 represent the average counts obtained from these replicates. The containers and their contents were not agitated, and samples were pipetted from approximately $2 \cdot 5 \mathrm{~cm}$. below the surface. The results show that 
under quiescent conditions no significant increase in numbers of bacteria took place in the water stored in the Pyrex, flint, or silica containers, but a marked increase in the gutta percha and Bohemian glass containers.

Table 1. Plate counts of bacteria in Windermere water stored in (a) 1 l. Pyrex conical flasks, (b) $32 \mathrm{oz}$. flint glass bottles and $(c)$ in 1 l. gutta percha stoppered containers for 4 days at $20^{\circ}$

\begin{tabular}{|c|c|c|c|}
\hline \multirow[b]{2}{*}{$\begin{array}{c}\text { Incubation } \\
\text { period (days) }\end{array}$} & \multicolumn{3}{|c|}{ Counts (thousands/ml.) } \\
\hline & Pyrex flasks & $32 \mathrm{oz}$. bottles & $\begin{array}{c}\text { Gutta percha } \\
\text { containers }\end{array}$ \\
\hline 0 & $3 \cdot 4$ & $3 \cdot 4$ & $3 \cdot 4$ \\
\hline 1 & $6 \cdot 1$ & $5 \cdot 5$ & $4 \cdot 4$ \\
\hline 2 & $11 \cdot 0$ & $10 \cdot 0$ & $129 \cdot 0$ \\
\hline 3 & $10 \cdot 0$ & $10 \cdot 0$ & $97 \cdot 0$ \\
\hline
\end{tabular}

In a third test three replicate Winchester quart ( 1 l.) bottles were compared with 11 . Pyrex conical flasks, each containing $500 \mathrm{ml}$. of Windermere water, the water being agitated by rotation of the container before sampling. The results (Table 2) show the enhanced bacterial count in the water in the Winchester bottles.

Table 2. Plate counts of bacteria in replicate samples of Windermere water incubated in Winchester bottles and in Pyrex flasks of 1 l. capacity

\begin{tabular}{|c|c|c|c|c|c|c|c|c|}
\hline \multirow{3}{*}{$\begin{array}{c}\text { Incubation } \\
\text { period (days) }\end{array}$} & \multicolumn{4}{|c|}{1 l. Winchester bottles } & \multicolumn{4}{|c|}{ 1 1. Pyrex flasks } \\
\hline & 1 & 2 & 3 & Av. & 1 & 2 & 3 & Av. \\
\hline & \multicolumn{4}{|c|}{ Counts (thousands $/ \mathrm{ml}$.) } & \multicolumn{4}{|c|}{ Counts (thousands $/ \mathrm{ml}$ ) } \\
\hline & 16 & 16 & 16 & 16 & 16 & 16 & 16 & 16 \\
\hline 1 & 142 & 260 & 44 & 148 & 22 & 44 & 26 & 31 \\
\hline 2 & 227 & 250 & 122 & 200 & 52 & 50 & 42 & 48 \\
\hline 3 & 252 & 235 & 125 & 205 & 5 & 10 & 8 & 8 \\
\hline
\end{tabular}

The results of the three experiments indicate that when Windermere water was stored in containers made of relatively insoluble materials no significant multiplication of bacteria took place. When, however, the container was agitated so as to remove bacteria developing on the glass surface the bacterial count increased, and this increase was greater in the containers made of soft glass (Winchesters) than in those made of resistance glass. Consequently, it was decided to determine whether the apparent multiplication of bacteria in stored water was connected with the growth of bacteria on the glass surface.

The effect of agitation. To ascertain whether bacterial growth in stored samples of water might not take place partly, or entirely, on the walls of the container, samples were taken from water $(a)$ kept under quiescent conditions and (b) after vigorous agitation. Five hundred $\mathrm{ml}$. amounts of Windermere water were stored in $1 \mathrm{l}$. Pyrex flasks, and on each sampling occasion three flasks were treated each as follows: (1) not agitated; (2) shaken vigorously before insertion of pipette, and after withdrawing sample returned to incubator; 
(3) shaken vigorously and discarded after sample had been taken. The results (Table 3) showed that although counts of bacteria increased in all samples, there were appreciably larger counts in the samples taken after agitation. It this appears that dislodgement of bacteria attached to the sides of the container by agitation was an appreciable factor in the apparent multiplication of bacteria in stored water.

Table 3. Plate counts of bacteria in Windermere water incubated in 1 l. Pyrex conical flasks for 4 days at $20^{\circ}$ (a) under quiescent conditions, (b) shaken on each sampling occasion and $(c)$ shaken once only

\begin{tabular}{cccc} 
Incubation & \multicolumn{3}{c}{ Counts (thousands/ml.) } \\
\cline { 2 - 4 } period (days) & Quiescent & Shaken once & Shaken daily \\
0 & $2 \cdot 1$ & $2 \cdot 1$ & $2 \cdot 1$ \\
1 & $5 \cdot 2$ & $5 \cdot 4$ & $4 \cdot 1$ \\
2 & $7 \cdot 8$ & $8 \cdot 6$ & $15 \cdot 8$ \\
3 & $5 \cdot 2$ & $13 \cdot 2$ & $13 \cdot 2$ \\
4 & $4 \cdot 7$ & $23 \cdot 4$ & $14 \cdot 6$
\end{tabular}

The effect of the size of container. Triplicate sets of Pyrex flasks of capacities 150,500 and $2000 \mathrm{ml}$. were filled to half-capacity with Windermere water and incubated under quiescent conditions. Very little increase in plate count took place, and the size of the container played no significant part (Table 4). A similar experiment with water from a polluted well showed (Fig. 3) that though bacteria grew appreciably in all containers the counts in different-sized containers did not differ significantly.

Table 4. Plate counts of bacteria in Windermere water incubated in Pyrex conical flasks of different capacities for 3 days at $20^{\circ}$

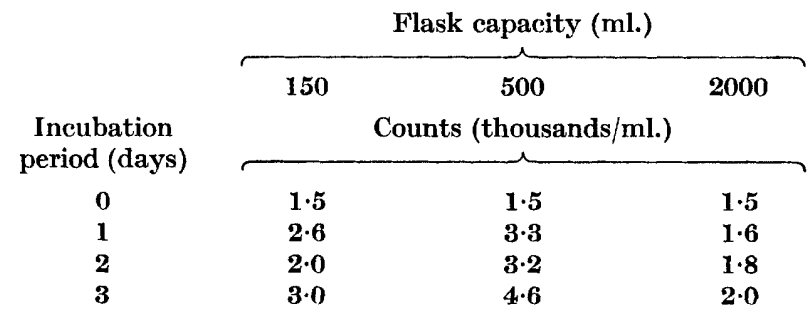

In a third experiment carried out in duplicate, bottles of $50,75,150,250$, 500 and $1500 \mathrm{ml}$. capacity were filled to approximately half-capacity with Windermere water, and agitated by vigorous rotational movements before sampling. The results with duplicate bottles of the smaller sizes (50 and $75 \mathrm{ml}$. amounts) were rather discrepant, but in general the bacteria multiplied more rapidly and to greater numbers in the smaller bottles (Table 5). As the bottles were not of the same brand and therefore not necessarily of the same chemical composition, the possible variation due to differing solubilities of the constituents cannot be entirely disregarded.

In a fourth experiment two sizes of Pyrex flasks, 150 and $1000 \mathrm{ml}$, were 
half-filled with polluted well water. On each sampling occasion two flasks of each size were agitated vigorously, sampled and returned to the incubator, and two flasks of each size which had not been sampled previously were similarly treated but discarded after sampling. The results showed (Fig. 4) that appreciably greater numbers of bacteria developed in the smaller flasks than in the larger, and that repeated agitation resulted in greater numbers than a single agitation; a result not in agreement with the finding with Windermere water.

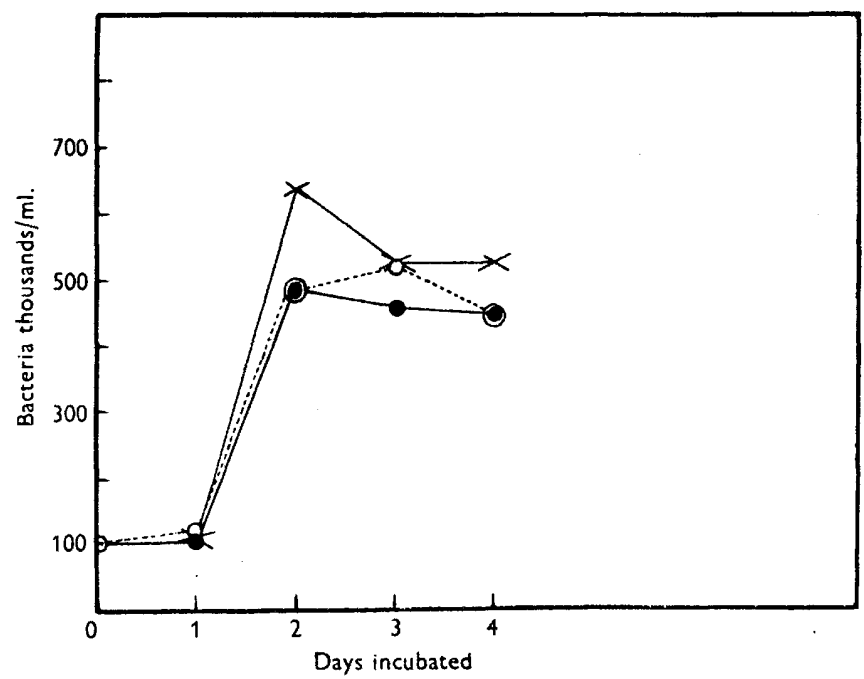

Fig. 3. Plate counts of bacteria in water from a polluted well incubated in Pyrex conical

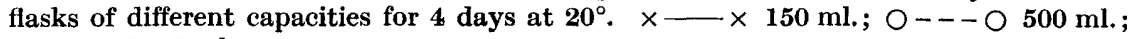
$2000 \mathrm{ml}$.

Table 5. Plate counts of bacteria in Windermere water incubated in bottles of different capacities for 3 days at $20^{\circ}$ and shaken before sampling

\begin{tabular}{|c|c|c|c|c|c|c|}
\hline \multirow{3}{*}{$\begin{array}{c}\text { Incubation } \\
\text { period } \\
\text { (days) }\end{array}$} & \multicolumn{6}{|c|}{ Bottle capacity (ml.) } \\
\hline & 50 & 75 & 150 & 250 & 500 & 1500 \\
\hline & \multicolumn{6}{|c|}{ Counts (thousands/ml.) } \\
\hline 0 & $2 \cdot 2$ & $2 \cdot 2$ & $2 \cdot 2$ & $2 \cdot 2$ & $2 \cdot 2$ & $2 \cdot 2$ \\
\hline 1 & $6 \cdot 2$ & $\mathbf{3} \cdot \mathbf{1}$ & $\mathbf{2} \cdot \mathbf{1}$ & $3 \cdot 7$ & $3 \cdot 0$ & $3 \cdot 3$ \\
\hline 2 & $79 \cdot 3$ & $75 \cdot 0$ & $43 \cdot 6$ & $10 \cdot 6$ & $24 \cdot 6$ & $12 \cdot 0$ \\
\hline $\mathbf{3}$ & $76 \cdot 2$ & $110 \cdot 3$ & $119 \cdot 4$ & $62 \cdot 2$ & $75 \cdot 0$ & $69 \cdot 3$ \\
\hline
\end{tabular}

In a fifth experiment triplicate sets of measuring cylinders of 25 and $1000 \mathrm{ml}$. capacities were filled with Windermere water. The water was allowed to remain undisturbed during incubation, and samples were withdrawn daily by means of a pipette; no contact of the pipette with the sides of the cylinders took place. The results (Table 6) were quite spectacular, for whereas the count in the water stored in the $1000 \mathrm{ml}$. cylinder increased from 2000 to a maximum of $12,200 / \mathrm{ml}$, the count in the $25 \mathrm{ml}$. cylinder increased to a maximum 
of $244,000 / \mathrm{ml}$, the highest figure ever recorded for Windermere water. This enormous difference in numbers of bacteria in the large and small cylinders bears no simple relationship to the small difference in the ratios of volume to surface area of the containers $\left(\mathrm{ml} . / \mathrm{cm} .{ }^{2}\right)$, which was 10.3 and 3.5 respectively.

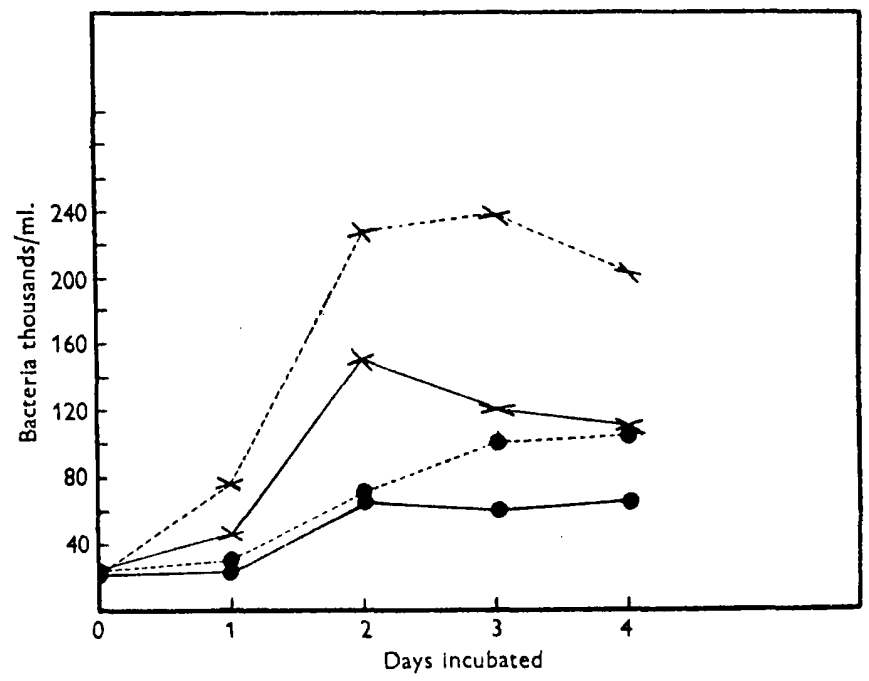

Fig. 4. Plate counts of bacteria in water from a polluted well incubated in 150 and $1000 \mathrm{ml}$. Pyrex conical flasks for 4 days at $20^{\circ}$. One set of flasks was shaken on each occasion and one set shaken only at the time of sampling and subsequently discarded. $x---x$ $150 \mathrm{ml}$. shaken each time; $\times-\times 150 \mathrm{ml}$. shaken once; $--1000 \mathrm{ml}$. shaken each time;

$1000 \mathrm{ml}$. shaken once.

Table 6. Plate counts of bacteria in Windermere water incubated under quiescent conditions in glass measuring cylinders for 4 days at $20^{\circ}$

\begin{tabular}{ccr}
$\begin{array}{c}\text { Incubation } \\
\text { period } \\
\text { (days) }\end{array}$ & $\begin{array}{c}25 \\
\text { Counts (thousands } / \text { ml.) }\end{array}$ \\
\cline { 2 - 2 } 0 & $2 \cdot 0$ & $2 \cdot 0$ \\
1 & $6 \cdot 8$ & $3 \cdot 4$ \\
2 & $243 \cdot 6$ & $10 \cdot 6$ \\
3 & $115 \cdot 0$ & $8 \cdot 6$ \\
4 & $142 \cdot 2$ & $12 \cdot 2$
\end{tabular}

\section{Chemical estimation of organic matter}

Oxygen absorbed from acidified $\mathrm{KMnO}_{4}$. In view of the claims (ZoBell, 1943) that organic matter is adsorbed from water on to the glass surface of a bottle, and can be demonstrated by chemical analyses using the permanganate or bichromate reduction tests, we have made extensive tests with $0.0125 \mathrm{~N}-\mathrm{KMnO}_{4}$ acidified by $25 \%(\mathrm{v} / \mathrm{v}) \mathrm{H}_{2} \mathrm{SO}_{4}$. Boiling the reagents and sample for a specified time gave unsatisfactory and unreproducible results, but the method commonly 
used in Britain of incubation for $4 \mathrm{hr}$. at a temperature of $80^{\circ} \mathrm{F}$. $\left(26 \cdot 7^{\circ} \mathrm{C}\right.$.) gave reproducible results. Taylor (1947) showed that $\mathrm{KMnO}_{4}$ in distilled water in the presence of a dried glass surface was appreciably and inexplicably reduced. When the glass surface was increased by adding glass balls, the amount of oxygen absorbed from the acid permanganate in the absence of organic matter was as great or greater than the oxygen absorbed by permanganate from water taken from Windermere and other local sources. Consequently, ZoBell's (1943) experiments with glass beads, glass-wool, and glass tubes, cannot be interpreted as measuring organic matter only; they need repeating with adequate controls.

Table 7. Oxygen absorbed from acid permanganate (p.p.m.) from waters (1) freshly gathered, (2) after storage at $20^{\circ}$ for 16 days and (3) by the surface of the container after a similar period

$\begin{array}{lcccc} & \text { Start } & 16 \text { days } & \text { Difference } & \text { Glass surface } \\ \text { Blelham Tarn } & 1.84 & 1.84 & 0 \cdot 00 & 0 \cdot 12 \\ \text { Inflow I } & 2 \cdot 18 & 1.94 & -0 \cdot 24 & 0 \cdot 29 \\ \text { Inflow II } & 2 \cdot 04 & 1.87 & -0 \cdot 17 & 0 \cdot 36 \\ \text { Inflow III } & 0 \cdot 64 & 0 \cdot 54 & -0 \cdot 10 & 0 \cdot 22 \\ \text { Windermere } & 0.78 & 0 \cdot 70 & -0 \cdot 08 & 0.00 \\ \text { Windermere+glass beads } & 1 \cdot 28 & 1 \cdot 21 & -0.07 & 0 \cdot 38\end{array}$

Measured amounts of water $(100 \mathrm{ml}$.) were placed in bottles, and the oxygen absorbed from acidified $\mathrm{KMnO}_{4}$ was determined (1) at once, (2) after periods of incubation at $20^{\circ},(3)$ after the same periods but with careful decantation of the water and replacement with an equal volume of freshly distilled water. The results of a typical experiment are shown in Table 7 .

It is evident that the organic-matter content of the water decreased during storage, particularly that of waters flowing into Blelham Tarn, but the amounts were extremely small and there was nothing to suggest that the glass surface, particularly that of $150 \mathrm{~g}$. glass beads of $2-3 \mathrm{~mm}$. diameter, favoured the decomposition of the organic matter. On the other hand, when the surface of the glass was tested for organic matter it could be detected with all samples except that of Windermere water. In a repeated experiment with water from Windermere, Blelham Tarn and a well, tests for organic matter were negative.

Oxygen consumed (biochemical oxygen demand). If organic matter is adsorbed on the glass surface and is therefore more readily available for bacterial decomposition, the oxygen demand of water stored in small vessels should be greater than that of water stored in large vessels, owing to the relatively greater surface of glass available in the smaller container. According to ZoBell $\&$ Anderson (1936) this happens with stored sea water; but with lake water, ZoBell \& Stadler (1940) found no significant difference between the amounts of oxygen consumed in samples incubated in 145 and $4000 \mathrm{ml}$. amounts. We have made similar tests with water from local lakes in a range of bottles of different sizes, making allowances for the volumes of reagents to be added. A constant-temperature water-bath at $20^{\circ}$ was used for incubation, and sets 
of three bottles were analyzed on each occasion. The results exemplified in Table 8 show that with lake water the size of the container does not affect the amount of organic matter decomposed by bacteria. The organic matter in these waters is so resistant to bacterial attack and so slowly broken down that its concentration is unlikely to influence its rate of decomposition. It is, however, possible that in very dilute solutions of sewage effluents, in which the organic matter was readily available, its concentration might influence the total amount decomposed or the rate of decomposition.

'Table 8. Biochemical oxygen demand (p.p.m.) of water from Blelham Tarn incubated in bottles of different capacities at $20^{\circ}$ for different periods

\begin{tabular}{|c|c|c|c|}
\hline \multirow{3}{*}{$\begin{array}{l}\text { Capacity of } \\
\text { bottle (ml.) }\end{array}$} & \multicolumn{3}{|c|}{ Days incubated } \\
\hline & 2 & 5 & 10 \\
\hline & \multicolumn{3}{|c|}{ Biochemical oxygen demand (p.p.m.) } \\
\hline 70 & $0 \cdot 49$ & $0 \cdot 85$ & $1 \cdot 15$ \\
\hline 140 & 0.49 & 0.86 & $1 \cdot 26$ \\
\hline 250 & $0 \cdot 45$ & 0.87 & $1 \cdot 29$ \\
\hline 400 & 0.43 & $0 \cdot 83$ & $1 \cdot 15$ \\
\hline 140 & - & $\mathbf{0 . 2 9}$ & $0 \cdot 52$ \\
\hline 2700 & - & $0 \cdot 32$ & $0 \cdot 51$ \\
\hline
\end{tabular}

\section{DISCUSSION}

In this study two facts can be accepted as well established. First, when waters, including distilled water, are stored in glass containers and sampled from time to time by a bacteriological routine including shaking the container, the bacteria appear to multiply to numbers greatly in excess of those found in the water under natural conditions. Secondly, low storage temperatures repress multiplication and raised temperatures usually increase it. Before considering our results it would be well to consider the changes which must result in water from the sea, lakes, rivers or wells when it is stored in comparatively small containers. In the first place natural circulation ceases and some particulate matter settles to the bottom of the container; any planktonic animals die, and if the container is stored in darkness, algal cells also perish. In addition, the solid surfaces of the walls of the container are available for the attachment of periphytic types of bacteria. If we assume that phosphorus and other essential inorganic ions are present, as is almost invariably the case, the water is an extremely dilute medium for the growth of bacteria, and the degree of growth will depend on the supplies of nitrogen, carbon and sources of energy. To some extent these materials are provided by dead planktonic cells. There is evidence also that whereas the freshly sampled water may contain a great variety of bacteria, storage conditions act selectively and encourage only a small proportion of the types originally present. Thus the dead cells of the types unable to grow may provide further nourishment for the selected types.

Our experiments show that when samples of water are stored in containers of resistance glass or silica the numbers of bacteria found are invariably greater 
when the container is shaken before sampling than when quiescent conditions are maintained; under quiescent conditions there is often no significant increase in numbers of bacteria. The agitation of the samples removes from the sides of the container those types of bacteria which are dependent for their existence on the presence of a solid surface and which under natural conditions are dependent on solid particles in suspension. Under such quiescent conditions of storage the bacterial numbers are similar to those in natural conditions.

The effect of the composition of the container is no less striking. No material is completely insoluble in the presence of water, and it is well known that soft glass is far more soluble than resistance glass. The evidence suggests strongly that water-soluble substances are here stimulating bacterial activity. A comparison of the chemical composition of soft and resistance glass suggests that sodium, potassium, calcium, magnesium or sulphate ions might be responsible agents.

Workers, in general, have given little information about the amount their experimental containers were shaken before sampling, or about their composition; and the discordant results reported may be due in part to variations in technique in this regard. Castell \& McDermott (1941) were perplexed that a well water having an average bacterial count of less than $10 / \mathrm{ml}$. when stored for 4 days yielded a count of $c .1$ million $/ \mathrm{ml}$; in this instance conditions were more complex. Their chemical analyses suggest that the water contained an appreciable amount of organic matter (volatile soluble substances 100 p.p.m.), and an exceptional amount of magnesium (250 p.p.m.). A very varied collection of containers was used in the experiment, but probably the most significant point was the increase in temperature from that of the well (unstated) to room temperature $\left(25^{\circ}\right)$, at which the samples were incubated.

ZoBell's hypothesis of the adsorption of organic matter on the walls of the container has not been confirmed; and it cannot be entirely refuted. Determinations of oxygen consumed and oxygen absorbed from acid permanganate show that organic matter in the water has been broken down, but we have no evidence that an increase in surface area in relation to the volume of the container increases the amount of organic matter decomposed, as would be expected if ZoBell's theory were correct. On the other hand, bacteriological tests indicate the growth of bacteria on the walls of the container, and, with some waters, organic matter is demonstrable on the sides of the container. On the available evidence we conclude that with lake and tarn waters such organic matter as may develop on the sides of a container is due to that of bacterial cells. Such a conclusion would reconcile the results of tests for oxygen consumed in bottles of different sizes with tests for organic matter adsorbed on the glass surface.

\section{REFERENCES}

Casteld, C. H. \& McDermott, L. A. (1941). Multiplication of bacteria in water and its significance in food spoilage. Food Res. 7, 244.

Frankland, P. \& Frankland, Mrs P. (1894). Micro-organisms in Water. London: Longmans, Green and Co. 
Harvey, H. W. (1941). On changes taking place in sea water during storage. J. Mar. Biol. Ass. U.K. 25, 225.

LLoyd, B. (1937). Bacteria in stored sea water. J.R. tech. Coll. Glasg. 4, 173.

Stark, W. H., Stadler, J. \& McCoy, E. (1938). Some factors affecting the bacterial population of fresh-water lakes. J. Bact. 36, 653.

TAYLOR, C. B. (1940). Bacteriology of fresh water. I. Distribution of bacteria in English lakes. J. Hyg., Camb., 40, 616.

TAYLOR, C. B. (1947). Reduction of potassium permanganate in the presence of glass. Nature, Lond., $160,56$.

Whipple, G. C. (1901). Changes that take place in the bacterial content of waters during transportation. Tech. Quart. 14, 21.

ZoBelt, C. E. (1943). The effect of solid surfaces upon bacterial activity. J. Bact. 46, 39.

ZoBel,, C. E. (1946). Marine Microbiology. Waltham, Mass. : Chronica Botanica Co.

ZoBell, C. E. \& ANDERson, D. Q. (1936). Observations on the multiplication of bacteria in different volumes of stored sea water and the influence of oxygen tension and solid surfaces. Biol. Bull. Woods Hole, 71, 324.

ZoBell, C. E. \& GranT, C. W. (1943). Bacterial utilization of low concentrations of organic matter. J. Bact. $45,555$.

ZoBel., C. E. \& Stadler, J. (1940). The effect of oxygen tension on the oxygen uptake of lake bacteria. J. Bact. 39, 307. 